\title{
CORPORATE LIABILITY UNDER MALAYSIAN OCCUPATIONAL SAFETY AND HEALTH LEGISLATION
}

\author{
Kamal Halili Hassan \\ Universiti Kebangsaan Malaysia
}

\begin{abstract}
Although the underlying philosophy of the Malaysian Occupational Safety and Health Act 1994 has always been self-regulatory, enforcement of the Act has relied on prosecution. The Act provides for several forms of sanctions- imprisonment and fines - to punish wrongdoers, who are mainly corporate bodies. Scores of corporate entities have been prosecuted since the promulgation of the Act in 1994; the overwhelming majority of these entities charged under the Act pleaded guilty and paid fines. This study found that corporate entities have generally been willing to pay fines rather than undergo criminal trials under the Act. Cases from the 2006-2013period prove the consistency of such pattern. The reasons for paying fines rather than undergoing criminal trial include the following, among others: the fines are comparatively low, the burden of proof is on the accused (in practice), the intensity and time factor of a full trial is onerous and the company's reputation is at risk. In the case of workplace-related death and its effect on corporations, the laws of the United Kingdom are analysed. This study adopted a qualitative method that mainly relied on descriptive and analytical examinations of statutory provisions and case law.
\end{abstract}

Keywords: Malaysia; OSHA 1994; Corporate Liability; Prosecution; Safety and Health.

\section{INTRODUCTION}

Corporations are potential offenders under the Occupational Safety and Health Act 1994 (Malaysia) (OSHA). In their capacity as employers (and perhaps as entrepreneurs), corporations undertake the performance of tasks that might cause injuries or death to their workers and harm to the public (Hassan, 2012; Rahman \& Hassan, 2008). The corporate liability for such calamities can be severe, and corporations might be required to pay huge sums of money as penalties under the Act. In addition, industrial accidents caused by the negligence of corporations might tarnish the reputation of such corporations. Thus, it is the aim of this paper to discuss corporate liability as provided under OSHA by referring to the pattern of liability in Malaysia during a given period and the challenges of enforcing the Act. Corporate liability for fatality cases is also discussed; however, because there has been no legislation on corporate liability for homicide/manslaughter in Malaysia, reference is made to United Kingdom law (Ali, 2009).

2 Corresponding author: Faculty of Law, Universiti Kebangsaan Malaysia, 43600, Bangi, Selangor, Malaysia.Email: kamalhalili60@ gmail.com 
It is axiomatic that the success of any legislation depends on its implementation and enforcement. However noble a legislation's objective, it will not be effective if enforcement is weak. For any legislation to be respected, it must have a positive impact on the industry and society. The same argument applies to the Occupational Safety and Health Act of 1994, which has become the primary legislation for ensuring and maintaining occupational and industrial safety. The number of industrial accidents and occupational diseases is increasing at an alarming rate, and OSHA has an important role in acting as a catalyst to create safety awareness among employers and employees (Hassan, 2002; Hassan et al 2010; Ismail et al 2009).

OSHA provides for several enforcement mechanisms. The Act provides for administrative measures such as campaign awareness, awards and standards certification, although its implementation continues to rely on legal enforcement (prosecution). To that end, Section 39 of the Act provides for various powers of enforcement to Occupational Health and Safety Officers, such as the power to enter premises, to inspect, to investigate, to confiscate and to take samples. Section 40 authorises officers to enter premises with a search warrant and to seize property, and section 41 authorises officers to enter premises without a search warrant. Section 42 provides for forceful entry into premises, section 43 provides for the steps that are required to be taken by officers during the inspection of premises, and section 44 authorises investigative powers. The investigation power under section 44 is akin to the power of the police in an investigation - without the power to arrest without a warrant that police officers have under the Criminal Procedure Code for any seizable offence. Section 45 concerns the power to examine witnesses. All these powers may be exercised by the Department of Occupational Safety and Health (DOSH) before it decides to prosecute a corporate body or not. In addition to prosecution, DOSH is authorised to issue notices, including improvement and prohibition notices (section 48). DOSH may prosecute corporate entities in the event that they fail to satisfy requirements contained in notices. It may also directly prosecute these entities for offences committed under the Act (Hassan, 2012; Bahari 2002).

This paper examines the prosecution power under the Act, the types of offences committed, the pattern of fines imposed by courts and other related issues, such as burden of proof. At this juncture, it is instructive to note that the overwhelming majority of corporate bodies prosecuted under the Act plead guilty. The amount of fines imposed by courts varies from case to case.

\section{LITERATURE REVIEW}

Although there is increasing concern about industrial safety in Malaysia, there is remarkably little literature (in the form of books) in Malaysia about occupational safety and health law. There is a gap in legal literature relating to corporate criminal liability cases under OSHA 1994. Thus, we will briefly canvas certain authoritative western literature on the subject. Barret \& Howells (2000) Occupational health and safety law: text and materials is a primary piece outlining the duties of the relevant parties -particularly the employer -in occupational safety and health. It covers many aspects of industrial safety laws, such as the concept of risk management, framework of civil liability, liability for personal injury, common negligence, breach of statutory duty, defences, criminal liability and the regulatory system in Great Britain. Explanations on statutory duty and criminal liability are relevant to the discussion of this 
article. Law of Health and Safety at Work: The New Approach by Drake \& Wright (1983) is a good text on this subject that discusses current issues in the English Health and Safety at Work legislation. Barret \& Howells (1997) Occupational health and safety law - framework outlines the law in England by analysing the roles of both civil and criminal laws in industrial safety. Ashford \& Caldert (1996) Technology, law and the working environment discusses the legal contribution in ensuring safety in modern industry. A new book by Forlin (2012) entitled Corporate liability: work related death and criminal prosecutions is a good and instructive book that analyses corporate criminal liability. Because perpetrators of industrial offences are mostly corporate bodies, this book is a good guide for prosecutors who are filing charges against companies and organisations that have violated industrial safety legislation.

Hassan and Rahman (2014) “Undang-undang keselamatan industri di Malaysia $2^{\text {nd }}$ Edition”, is the first local book that describes the law of industrial safety in Malaysia. It explains the objectives, scope and governance of occupational safety in Malaysia, in addition to the roles of employers, employees, designers, manufacturers, suppliers, the enforcement of the Act, salient features of the Factory and Machineries Act 1867, the law of employees' social security and international labour standards. The chapter on enforcement of the Act is relevant to the subject of this article. The book from Bahari (2002) entitled "Pengaturan sendiri di dalam pengurusan keselamatan dan kesihatan pekerjaan" contributes to the local literature on the subject, although it focuses not on the law but on safety and health management at the workplace. In addition, there have been articles written on Malaysian occupational safety and health law. Hassan (2012) wrote an article entitled "Kewajipan majikan di bawah seksyen 15-18 Akta Keselamatan dan Kesihatan Pekerjaan" that primarily discusses the duty of employers to ensure safety at the workplace to employees and other persons; it also notably discusses the duty of an employer to contractors and workers employed by contractors. The employer has a duty to contractors as long as the employer has control over the contractors. The definition and extent of the control required is a question of fact but Hassan argues therein that the employer has control over the contractor if the employer has the capacity to control the nature of the work and its manner. Control and liability can be absolved by the employer via terms to that effect drafted in an agreement.

The literature discussed above focuses mainly on employers' duties to ensure safety at the workplace. However, they do not discuss corporate criminal liability under OSHA 1994 extensively. This article therefore will fill this gap in the literature by analysing the pattern of statutory breaches by Malaysian companies under the Act. The primary legislation referred to is the Occupational Safety and Health Act 1994. Charges have been filed against corporate bodies that have violated provisions under the Act. However, because most offenders pleaded guilty, the cases have not gone to full trial and are therefore unreported in mainstream journals, such as the Malayan Law Journal. As a result, there is a void in legal literature relating to corporate criminal liability cases under OSHA 1994. Alternatively, a publication from DOSH/ JKKP entitled Jurnal Pendakwaan, Jabatan Keselamatan dan Kesihatan Pekerjaan 2009 \& 2010 and again under the same title published in 2011 contain a record of charges levelled against corporate bodies. As discussed above, because the companies pleaded guilty, we can only identify the pattern of offences and sentencing imposed on them; this stands in contrast to common-law cases in which elaborate discussions have been delivered by judges on many issues of occupational safety. 


\section{METHODOLOGY}

The research methodology adopted in this paper is 'contents analysis' through the application of a qualitative approach called a conventional or legalistic study (Yaqin 2007; Zahraa 1998). The approach of the paper is doctrinal, which indicates that it rests on theoretical, academic or conventional research. This paper discusses and adapts the legal protections under Malaysian occupational safety and health law. The research methodology applied is jurisprudential content analysis. Content analysis is applied with an analytical and critical approach throughout the paper. The study is further based on the arm chair research method, which is essentially a library-based study, which means that the material required for the research should be available in libraries, archives and databases. The basic aim of this paper is to discover, explain, examine, analyse and present facts, principles, provisions, concepts, theories or workings of certain laws in a systematic form; thus, it is a qualitative study. This paper also relies on data collected from government publications. To understand the pattern and issues involved in the sentencing of criminal liabilities by offenders under the OSHA 1994, the researcher adapts the data that appeared in Jurnal Pendakwaan, Jabatan Keselamatan dan Kesihatan Pekerjaan 2009 \& 2010 and 2011 respectively published by Jabatan Keselamatan dan Kesihatan Pekerjaan, Putra Jaya, Malaysia. The main legislation referred to in this article is OSHA 1994. For issues of corporate manslaughter/homicide, reference is made to commonlaw cases in the United Kingdom.

\section{CORPORATE CRIMINAL PREVENTION}

Preventing industrial accidents can be viewed from the perspective of both civil and criminal liabilities. An extensive amount has been written in and about common-law courts concerning civil liability for industrial accidents, particularly in the context of the law of torts. Under tort law, briefly, an employer, occupier or employee has the duty of care not to injure any other person. That any other person in the law of tort is called a neighbour, and thus we have the neighbour principle that derived from the principles found in the famous case of Donough $v$ Stevenson [1932] AC 562. In that case, the plaintiff suffered from nervous shock after drinking ginger beer from an opaque bottle which contained a snail. This case gave rise to a claim based on a cause of action from a consumer directly to a manufacturer. There was no contract between the consumer and the manufacturer in that case, but the neighbour principle allowed the consumer to sue the manufacturer. The consumer has a duty of care towards all consumers who will likely suffer damage as a result of his actions in breaching that duty. Such breach of the duty of care must result in direct damage to the defendant. Such damage must be not too remote, and there should also be no supervening factor or event that breaks the chain of causation between the duty of care and the breach of such duty. For example, if the defendant causes fire to occur on a premises but the damage to the plaintiff's property is caused by winds blowing the fire towards the defendant's far-off property, the plaintiff is not liable because there is a supervening event that occurred between the duty and its breach. It is also too remote for the plaintiff to assume or foresee that winds might suddenly blow and carry the spark of fire toward the defendant's premises.

Malaysian cases that followed the Donoghue's principle are Sivakumaran a/l Selvaraj\& 2 Ors (Suing Through Their Mother and Next Friend, Selvi a/p Muthusamy) \& Anor v Yu Pan \& Anor [1995] 1 AMR 490; Uniphone Sdn. Bhd. v Chin Boon Lit \& Anor [1998] 6 MLJ 
441 and Arab-Malaysian Finance Bhd v Steven Phoa Cheng Loon \&Ors [2003] 2 AMR 6. Reading from the case of Uniphone, the Malaysian courts seem to distinguish the standard of duty of care between tortuous act that had resulted in physical damage or purely on economic loss. If it is the former, the court would apply the Donoghue's principle, i.e. limited to the foreseability of damage alone, and if it is pure economic loss an additional level of standard is required which is 'whether in the circumstances it is fair, just and reasonable to impose a duty'. However in Arab-Malaysian Finance's case, the court retreated to the Donoghue's principle. In short, where the plaintiff suffers damage to his property or body, where such damage is foreseeable, the 'neighbour principle' which forms the basis of the duty of care as established by Donoghue's case will apply regardless of the types of tortuous act (Talib, 2003).

To demonstrate causation in tort law, plaintiffs must establish that the loss that they have suffered was directly caused by the defendant. In most cases, the 'but for' test will resolve the question of causation in tort law, i.e., 'but for' the defendant's actions, would the plaintiff have suffered the loss? If yes, the defendant is liable. If otherwise, the defendant is not liable. Causation may be problematic where there is more than one possible cause, and various formulations have evolved to ease the burden of proving causation in such situations. The application of the 'but for' test in establishing causation in tort law have been discussed in cases such as Barnett $v$ Chelsea \& Kensington Hospital [1969] 1 QB 428 and Chester v Afshar [2004] 3 WLR 927. The remedy under tort law is in the form of compensation to the successful plaintiff in his suit, which is considered as an apology and redress for loss suffered. Under modern social security law, it is insurance companies or a state fund that typically pays compensation to the plaintiff.

This paper's primary aim is to discuss the role of criminal law in preventing mishaps or accidents at workplaces. Unlike tort law, which uses civil remedies, criminal law does not compensate victims; instead, it punishes offenders. The aim of the law is prevention and deterrence not compensation. The punishment meted out under criminal law is expected to work as a deterrent so that potential offenders will avoid committing the offence in the future. Whether the deterrence works or not in practice is well outside the scope of this paper, but it is arguably the best sentencing policy that criminal law may offer. The OSHA 1994 is criminal legislation because it imposes punishment in the form of imprisonment and/or fines on the offenders. (Under section 59, the Act explicitly cannot be used as a medium for applying civil remedies). For example, the penalty for offences under sections 15, 16, 17 or 18 carries a punishment of a fine not to exceed fifty thousand ringgit or imprisonment for a term not to exceed two years or both (section 19). The Act also provides a general penalty that provides for no specific penalty, but that carries a fine not to exceed ten thousand ringgit or imprisonment for a term not to exceed one year or both. In the case of a continuing offence, the punishment consists of a fine not to exceed one thousand ringgit for every day or part thereof during which the offence continues after conviction (section 51).

Section 61 provides for prosecution by the occupational safety and health officer or an officer specially authorised in writing by the Director-General. The power to prosecute cannot be undertaken without the consent of the Public Prosecutor of the Attorney General Chambers. Such consent must be obtained in every case instituted by the Department of Occupational Safety and Health (DOSH), and the document of consent to prosecute must be tendered in court as an exhibit. When the power to prosecute derives from section 377 (b) of the Criminal 
Procedure Code, a copy of the section must be tendered in court as an exhibit. Section 62 provides for compounded offences; however such power to compound cannot be currently exercised because it has not yet been published in the Gazette. Consequently, all offences under OSHA 1994 must be prosecuted in courts (Hassan and Rahman, 2014).

Section 52 provides for offences committed by body corporate. A body corporate is an entity created by law, such as by the Companies Act. It has its own personal legal identity, which means that it can sue and be sued in its own name in civil actions. It can also be charged under the criminal law in its own name. Thus, in this context, a body corporate is like person who is subject to sanctions of criminal law. However, a body corporate cannot be imprisoned; section 56 thus provides that "where a person convicted in respect of an offence .... is a body corporate or a trade union, it shall only be liable to the imposition of a fine only". Under section 56, a natural person - such as a director, manager, secretary or officer - may be charged jointly with the corporations or severally. In the event that the persons mentioned are charged jointly with the body corporate they are employed by, such persons shall be deemed to be guilty of the offence if the body corporate is found guilty. The case data collected from DOSH have shown that all charges were filed against the body corporate and none against directors, managers, secretaries or officers of the body corporate. Thus it can be assumed that in Malaysia it is not the norm to charge the director, manager, secretary or officers of the body corporate for offences committed under OSHA 1994.

\section{RESULT AND DISCUSSION}

\subsection{Pattern Of Offences And Punishment Under OSHA 1994 And FMA 1967}

Table 1: Types of Actions under OSHA 1994 and FMA 1967: 2006-2013

\begin{tabular}{|c|c|c|c|c|c|c|c|c|c|}
\hline No. & Types of Actions & 2006 & 2006 & 2008 & 2009 & 2010 & 2011 & 2012 & 2013 \\
\hline 1 & Numbers of NOI/NOP & 5830 & 4878 & 5429 & 3407 & 5835 & 6261 & 15591 & 18186 \\
\hline 2 & Number of Compound & 779 & 215 & 14 & 259 & 223 & 234 & 466 & 415 \\
\hline 3 & $\begin{array}{l}\text { Number of Compound } \\
\text { (Fine in RM) }\end{array}$ & 73,864 & 28,741 & 2,000 & 225,666 & 36,290 & 711,446 & $1,459,350$ & $1,105,832$ \\
\hline 4 & Number of Prosecution & 49 & 108 & 135 & 149 & 170 & 183 & 247 & 350 \\
\hline 5 & $\begin{array}{l}\text { Number of Prosecution } \\
\text { (Fine in RM) }\end{array}$ & 21,200 & 28,800 & 284,250 & 444,750 & 536,150 & $1,151,500$ & $1,265,700$ & - \\
\hline
\end{tabular}

Source: Jabatan Keselamatan dan Kesihatan Pekerjaan . 2013. Maklumat dan Data Ringkas JKKP

Table 1 above shows the official statistic issued by DOSH on actions taken under the OSHA 1994 and the Factories and Machinery Act (FMA) 1967. The number of Notice of Improvement (NOI) and Notice of Prohibition (NOP) issued under OSHA shows an increase of notices issued by DOSH especially in 2012 and 2013. The number of compound issued under FMA has also increase in 2012 and 2013. Likewise, the number of prosecution made under both OSHA and FMA has also increase from 2006-2012. The yearly increase of legal actions taken by DOSH is as a result of the increasing number of employers and work places and official of DOSH itself. The problem with this data is that DOSH has lump together the number of prosecution made under OSHA and FMA. Thus the actual number of prosecution made against corporate bodies under OSHA is unclear. 
Table 2: Number of Prosecution under section 15(1) and section 17(1) of OSHA: 2008-2011

\begin{tabular}{ccc}
\hline Year & $\begin{array}{c}\text { Number of prosecution under section 15 } \\
\text { (Employer has breached his duty against its } \\
\text { own employees) }\end{array}$ & $\begin{array}{c}\text { Number of prosecution under section 17 } \\
\text { (Employer has breached his duty against } \\
\text { non-employees) }\end{array}$ \\
\hline 2008 & 3 & 2 \\
2009 & 15 & 7 \\
2010 & 21 & 10 \\
2011 & 36 & 27 \\
\hline
\end{tabular}

Source: Jabatan Keselamatan dan Kesihatan Pekerjaan. 2010. Jurnal Pendakwaan JKKP 2009 \& 2010.

Jabatan Keselamatan dan Kesihatan Pekerjaan. 2011. Jurnal Pendakwaan JKKP 2011.

Table 2 shows the number of cases reported for offences under the OSHA 1994. Most prosecution is made under section 15 (1) and section 17(1) of OSHA respectively. Data were collected and accumulated based on states in Malaysia (as charges are filed against the corporate body operating in each state). Admittedly, there were some states which did not submit their data to the DOSH headquarter; thus the statistic accumulated from the DOSH Jurnal Pendakwaan is arguably not reflective of the total number of prosecution for the whole of Malaysia under the respective provisions of OSHA. Table 2 shows an increase number of prosecution under sections 15 (1) and 17(1) of OSHA from 2008-2011.

The purpose of table 3 below is to show the range of penalties imposed by courts under section 15 and section 17of OSHA respectively. In this table the respective years is not separated as the range of fines as imposed by courts is almost the same.

Table 3: The fines imposed against corporate bodies under section 15(1) or 15(2): 2008-2010

\section{Section/regulation where Penalties (amount of fine as imposed by courts) and companies charged frequency of the same amount of fine (in bracket)}

15(1) of OSHA, 1994.

Single charge (in italic).

Employer has breached his duty against his employees.

$$
\begin{aligned}
& R M 1,000-(1) \\
& R M 2,000 \text { - (1) } \\
& R M 5,000 \text { - (3) } \\
& R M 7,000 \text { - (1) }
\end{aligned}
$$

RM 8,000 (charged with other section) - (2)

$$
\begin{aligned}
& R M 8,500-(1) \\
& R M 10,000 \text { - (9) } \\
& R M 11,000 \text { - (1) } \\
& R M 12,000 \text { - (2) }
\end{aligned}
$$

RM 13,000 (charged with 3 other provisions) - (1)

$$
\begin{aligned}
& R M 18,000 \text { - (2) } \\
& R M 20,000 \text { - (4) } \\
& R M 25,000 \text { - (1) } \\
& R M 30,000 \text { - (2) }
\end{aligned}
$$

RM 35,000 (charged with other section) - (1)

$$
\text { RM 50,000 (s15(1)) - (1) }
$$


Table 4: The fines imposed against corporate bodies under section 17 of OSHA: 2008-2010.

\section{Section/regulation where companies charged}

Penalties (amount of fine as imposed by courts)

17(1) OSHA, 1994.

Single charge (in italic).

Employer has breached his

duty against non-employees

(other persons).
$R M 3,000$

RM 5,000

RM 6,000

$R M 8,000$

$R M 10,000$

RM 11,000

$R M 12,000$

RM 13,000 (charged with other section)

$R M 30,000$

RM 40,000

Source: Jabatan Keselamatan dan Kesihatan Pekerjaan. 2010. Jurnal Pendakwaan JKKP 2009 \& 2010. Jabatan Keselamatan dan Kesihatan Pekerjaan. 2011. Jurnal Pendakwaan JKKP 2011.

Table 3 and 4 above show offences committed under section 15(1) of OSHA where the lowest fine imposed by courts is RM 1,000.00 and the highest fine is RM 50,000.00. (The maximum fine for contravening this section is RM 50,000.00). The lowest fine is RM 1,000.00, imposed by the Magistrate Court, on Wujud Wawasan Sdn. Bhd., a construction company based in Pahang on 29 December 2010. The highest fine is RM 50,000.00, imposed by the Session Court Johor Baru, on Duramex Industries Sdn. Bhd., a manufacturing company on 2 October 2009. The fact of the Duramex's case submitted by the prosecution was that the employer has failed to provide a Standard Operation Procedure for welding work. The employee has suffered severe injury when the regulator meter burst and hit the employee's right eye and caused his right eye blind. The company never reported the accident to DOSH. Table 4 shows offences committed under section 17(1) of OSHA where the lowest fine imposed by court is RM 3,000.00 on Telic Paper Sdn Bhd., a construction company in Melaka on 23 January 2009. The highest fine is RM 40,000.00 (maximum fine is RM 50,000.00) imposed by the Session Court, Kota Tinggi Johor on FELDA Palm Industries Sdn, Bhd., a manufacturing company on 11 December 2008. All of the companies charged had pleaded guilty. Table 3 shows that the frequent fine imposed on companies for contravening section 15(1) is RM 10,000.00, with nine companies fined with that amount. In all cases, corporate bodies were charged alone; the persons employed by the companies were not jointly charged. The pattern seems to be that: almost all companies pleaded guilty; the amount of fines varies from offence to offence; no punishment of imprisonment was imposed (this is because no person employed by the company was charged); the most frequent fine imposed is RM10,000 for offence under section $15(1)$.

\section{BURDEN OF PROOF}

The burden of proof in criminal case always lies with the prosecution; the prosecution must prove that the elements in the charge have been satisfied, among other evidentiary requirements. For example, for offence under section 15(1) and (2) (a) of OSHA, the prosecution must prove 
that the employer has breached its duty of ensuring safety at its work place. The prosecution must thus submit and prove the fact, i.e., that the accident really occurred. Typically, the company notified DOSH about the accident, and the complaint report must be tendered in court. In addition, other exhibits tendered include documents from Suruhanjaya Syarikat Malaysia detailing the company's information, the employee/victim letter of offer, the medical report of the victim and original photos (with negatives). These documents are necessary to prove that the accident did occur, that the victim is the employee of the accused, the extent of the victim's injury and the legal entity of the accused (body corporate).

The prosecution must first prove a prima face case at the end of its case; if successful, the prosecution must next prove that the defendant is guilty beyond a reasonable doubt at the end of the entire case (i.e., after the defendant has presented its case). The prosecution must prove that the employer has breached its duty to ensure safety at the workplace. In other words, the breach of such duty led to the occurrence of the accident and the employee suffered damage. Although a corporate body is charged under the OSHA, the application of evidence in a trial under this Act is still bound by the Evidence Act. The main provision regarding burden of proof is sections 101 and 102 of the Evidence Act 1950 (MGI Securities v Teong Teck Leng, 2000, 5 CLJ 163). The standard of proof is based on the 'prudent man' test. This is based on section 3 of the Evidence Act that a fact is said to be 'proved' when after considering the matters before it, the court either believe itto exist or considers its existence so probable that a 'prudent man' ought, under the circumstances of the particular case, to act upon the supposition that it exists (PPv Yuvaraj, 19692 MLJ 89). Beyond reasonable doubt in criminal cases does not mean beyond a shadow of doubt. What is proof beyond reasonable doubt would depend on the facts and circumstances of the case and the quality of evidence adduced (Miller $v$ Minister of Pensions, 1947, 2 All ER 372). Mat v PP (1963, 29 MLJ 263) has elaborated the duty of the court in determining the standard of proof in criminal cases.

However, the extent of the employer's duty is subject to the proviso that the duty must only be discharged 'so far as is practicable'. Who would prove the extent of such duty? Section 60 of OSHA provides that the accused must prove that it was not practicable to do more than was in fact undertaken to satisfy the duty. The onus is shifted to the accused (company) to prove the material elements that it has practically undertaken the requirements necessary to ensure safety at its work place. In the case of shifting the burden of proof to the accused who has special knowledge, reliance can be made to section 106 of the Evidence Act 1950. Cases such as PP v Hoo Chee Keong (2000, 5 MLJ 448), PP v Lim Kwai Thean (1959, 1 MLJ 179), Lee Chin Hock V PP (1972, 2 MLJ 30) and Mary Ng $v$ R (1958 MLJ 108) can be referred to explain the situation where the accused has to prove certain matters which he has special knowledge. It is submitted that it would not be easy for the accused to discharge this burden. We believe that is one reason that most OSHA cases end with a guilty plea.

\section{LIABILITY OF CORPORATE ENTITY IN FATALITY CASES}

Cases of industrial death or fatality have been reported. The offender (a person) may be charged for offence resulting from such fatality. He may be charged either under OSHA 1994 or Penal Code. In such tragic case of fatality, the offender is most probably to be charged under Penal Code because the prosecution feels that a charge under OSHA will not bring a deterrent 
sentence. A person responsible for industrial death may be charged either under section 302 (for murder) or 304 (culpable homicide not amounting to murder) or 304A (causing death by negligence) of the Penal Code. It is not very likely that industrial death will result with the charge of murder under section 302. A charge for culpable homicide not amounting to murder under section 304 or causing death by negligence under section 304A is likely to be levelled against the offender. An interesting issue here is: can a corporate entity be charged for death or fatality due to occupational or industrial accident?

English Courts have dealt with the issue of corporate liability for manslaughter on several occasions. The House of Lords in Tesco Supermarkets Ltd v Nattrass (1972, AC 153) deliberated on this issue although it eventually allowed Tesco's appeal against conviction. The Court indicated that the principles of 'vicariously liability' and 'identification' can be applied on corporate body for the offence of manslaughter. The principle of corporate liability again came to be argued before the courts following the Zeebruger ferry disaster (Barret \& Howells 2000). The coroner conducting the inquest held that a corporation could not be indicted. The decision was however challenged by way of judicial review in $R v$ HM Coroner for East Kent ex p Spooner (1989, 88 Cr App R 10) and Bingham LJ said: "I am ... tentatively of opinion that, on appropriate facts, the mens rea required for manslaughter can be established against a corporation. I see no reason in principle why such a charge should not be established". After the inquest has completed, a criminal charge was levelled against the corporation (P\&O European Ferries (Dover) Ltd, 1991, 93 Cr APP R 72). In summing up his ground of decision, Turner J said: “ ... suffice it that where a corporation, through the controlling mind of one of its agents, does an act which fulfils the prerequisites of crime of manslaughter, it is properly indictable for the crime of manslaughter". However, in the end there were no convictions of manslaughter arising out of the Zubregge disaster due to the season that there was no individual sufficiently to be personally liable and thus no person with whose wrongdoing the company could be identified. The UK parliament has passed the Corporate Manslaughter and Corporate Homicide Act 2007 which came into effect on April 6, 2008 (Forlin 2005; 2006). Under this Act, corporations can be found guilty of corporate manslaughter (Forlin, 2012). So far corporations although charged for manslaughter were never held liable for it.

What would the position be in Malaysia? Can a corporation be charged for culpable homicide? (The term 'manslaughter' is not legally used in Malaysia). The law on the meaning and status of corporate entity as a legal person is well developed under company law but the law is silent on the position of corporate liability for offence of culpable homicide. There have been cases of industrial accidents which resulted in death of employees and non-employees. Examples of such incidents in Malaysia are cases pertaining to the Bright Sparklers explosion in 1991 (Shaluf, 2002), Jaya Supermarket collapse in 2009 (Lakshana, 2012) and Sunway Lagoon case. The Bright Sparklers explosion case was brought before a Royal Commission of Inquiry and the Inquiry found the company responsible for the fatal accident. However, the company or its agents/officers were not prosecuted in court.

In the Jaya Supermarket case, C.W. Yap Sdn Bhd., the contractor company was engaged to demolish an office building and a supermarket located at Jalan Semangat, Petaling Jaya. During the demolition work, the building collapsed and killed the company's employees and 
other persons (non-employees). The company was charged under section 17 of the OSHA and pleaded guilty. Later, Yap Choo Wai, the director of the company was also charged in the Session Court under the same section, and he also pleaded guilty (PP v Yap Choon Wai, MS378-2010).

In Jub'li Mohamed Taib Taral \&Ors v. Sunway Lagoon Sdn. Bhd., S9(S4)-23-72-98, the first plaintiff, his wife and his two children (the second and third plaintiffs) went to the Sunway Lagoon Theme Park to enjoy themselves. The defendant owned the said park. While he and his wife ('the deceased') were on the runaway train, his wife was flung out of the train and fell to death. The first plaintiff now claimed for damages for himself and his two infant children under s. 7 of the Civil Law Act 1956 together with special damages against the defendant. As liability was not contested, the only issue before the court was on the quantum of damages the plaintiffs were entitled to. The Session Court found the defendant liable and awarded damages to the plaintiffs.

Reference can also be made to non-industrial accident cases such as Yu Sang Cheong Sdn. Bhd. v PP (1973, 2 MLJ 77) and PP v Kedah \& Perlis Ferry Services Sdn. Bhd. (1978, 2 MLJ 221) which explain the legal standing of corporate body pertaining to mens rea i.e. the guilty mind as requirement for the conviction of a criminal act. In Yu Sang Cheong Sdn. Bhd, the company had been convicted of the offence of knowingly being in possession of certain prohibited goods. A question of law was referred to the Federal Court: whether a limited company can be guilty of criminal offence where mens rea is required and without proof of mens rea of its agent or officers. The Federal Court held that: 'as men rea was essential for proof of guilt, the limited company could not be guilty of the offence without proof of mens rea of its agents or officers'. In Kedah \& Perlis Ferry Services Sdn. Bhd., the company was charged for 'being knowingly in possession' of un-customed goods. The High Court upheld the decision of the Session Court which did not find the company guilty. This is because the company's officers and agent had no knowledge that the goods were un-customed.

None of the cases have found the corporate entities liable for the death of persons. Furthermore, it is highly unlikely that in the near future a corporate body in Malaysia to be charged for corporate homicide considering that there is no legislation to that effect (Ali, 2009).

\section{CONCLUSION}

The statistic showed above proves that since promulgation of the OSHA in 1994, scores of corporate entities have been prosecuted. The overwhelming majority of the corporate entities charged under the Act pleaded guilty and paid the fines. This study found that corporate entities have generally been willing to pay fines rather than undergo criminal trials under the Act. Cases from the 2008-2010 period prove the consistency of such pattern. The reasons for paying fines rather than undergoing criminal trial include the following, among others: the fines are comparatively low, the burden of proof is on the accused (in practice), the intensity and time factor of a full trial is onerous and the company's reputation is at risk. In the case of industrial death, corporate entities in Malaysia have never been charged for culpable homicide offences. It is proposed that Malaysia should enact an Act on corporate culpable homicide. 
This would be an added protection to the employees and public at large as indicated by the House of Lords in the Tesco case (mentioned above) that 'making an employer criminally liable, even when he has done all that he could to prevent an offence, affords some additional protection to the public because this will induce him to do more'. Of course the corporate entity cannot be sent to prisons, but it can be fined and the heavy fine imposed will be a deterrent to other corporations.

\section{ACKNOWLEDGEMENT}

We wish to record our gratitude to Universiti Kebangsaan Malaysia for giving us a research grant, No: INDUSTRI-2012-005, and also to the anonymous assessors of this article.

\section{REFERENCES}

Ali, H. M. (2009). Corporate killing for Malaysia: a preliminary consideration. Jurnal Undangundang dan Masyarakat, 13,144-157.

Arab-Malaysian Finance Bhd v Steven Phoa Cheng Loon \& Ors [2003] 2 AMR 6.

Ashford, N. \& Caldert, C. (1996). Technology, law and the working environment. USA: Island Press.

Bahari, I. (2002). Pengaturan sendiri di dalam pengurusan keselamatan dan kesihatan pekerjaan. KL: MacGraw Hill.

Barnett v Chelsea \& Kensington Hospital [1969] 1 QB 428.

Barret, B. \& Howells, R. (2000). Occupational health and safety law: text and materials, $2^{\text {nd }}$ Ed. UK: Cavendish Publishing.

Barret, B., \& Howells, R. (1997). Occupational health and safety law - framework, $3^{\text {rd }}$ Ed. UK: Pitman.

Chester v Afshar [2004] 3 WLR 927.

Donough v Stevenson [1932] AC 562.

Drake, C. \& Wright, F. (1983). Law of health and safety at work: the new approach. UK: Sweet \& Maxwell.

Forlin, G. (2005). Corporate manslaughter bill: a new dawn? Archbold News, June, 6-8.

Forlin, G. (2006). Corporate manslaughter. Solicitor Journal, January, 42. 
Forlin, G. (2012). Corporate liability: work related death and criminal prosecutions, $3^{\text {rd }}$ edition. UK: Bloomsbury Profesional.

Hassan K. H., Ngah, C. A., Ismail, C. T., \& Rahim, R. A. (2010). Isu perundangan berhubung penyakit pekerjaan di Malaysia. Malayan Law Journal, 3, lxviii-xciv.

Hassan, K. H. (2002). Undang-undang keselamatan industri, piawaian ILO dan Malaysia. Malayan Law Journal, 1, xxxiv-xcvi.

Hassan, K. H. (2012). Kewajipan majikan di bawah seksyen 15-18 Akta Keselamatan dan Kesihatan Pekerjaan 1994. Malayan Law Journal, 2, lxv-lxxix.

Hassan, K. H., \& Rahman, R. A. (2014). Undang-undang keselamatan industri di Malaysia. Edisi Kedua. Kuala Lumpur: Dewan Bahasa dan Pustaka.

Ismail, C. T. M., Hassan, K. H., \& Ngah, A. C. (2009). Konsep dan pengertian 'penyakit pekerjaan. Jurnal Undang-Undang dan Masyarakat, 13, 55-71.

Jabatan Keselamatan dan Kesihatan Pekerjaan, (2013). Maklumat dan Data Ringkas, JKKP. Putra Jaya: Terbitan Jabatan Keselamatan dan Kesihatan Pekerjaan.

Jabatan Keselamatan dan Kesihatan Pekerjaan. (2010). Jurnal Pendakwaan, JKKP 2009 \& 2010. Putra Jaya: Terbitan Jabatan Keselamatan dan Kesihatan Pekerjaan.

Jabatan Keselamatan dan Kesihatan Pekerjaan. (2011). Jurnal Pendakwaan, JKKP 2011. Putra Jaya: Terbitan Jabatan Keselamatan dan Kesihatan Pekerjaan.

Jub'li Mohamed Taib Taral \& Ors v. Sunway Lagoon Sdn Bhd, S9(S4)-23-72-98.

Lakshana, M. (2012). Jaya supermarket case closed. The Malay Mail, 8 February.

Lee Chin Hock V PP [1972], 2 MLJ 30.

Mary Ng v R [1958] MLJ 108.

Mat v PP [1963] 29 MLJ 263.

MGI Securities v Teong Teck Leng, 2000, 5 CLJ 163.

Miller v Minister of Pensions [1947] 2 All ER 372.

PP v Hoo Chee Keong [2000] 5 MLJ 448.

PP v Kedah \& Perlis Ferry Services Sdn. Bhd. [1978] 2 MLJ 221. 
PP v Lim Kwai Thean [1959] 1 MLJ 179.

PP v Yap Choon Wai, MS3-78-2010 (unreported).

PP v Yuvaraj, [1969] 2 MLJ 89.

R v HM Coroner for East Kent ex p Spooner [1989] 88 Cr App R 10.

Rahman, R. A., \& Hassan, K. H. (2008). Regulating high-risk activities in construction industry in Malaysia: the need for legal protection. Jurnal Undang-Undang dan Masyarakat, 12, 246-258.

Shaluf, I. M. (2002). Bright sparklers fire and explosion: the lesson learned, Disaster Prevention and Management, 11(3), 214-221.

Sivakumaran a/l Selvaraj\& 2 Ors (Suing Through Their Mother and Next Friend, Selvi a/p Muthusamy) \& Anor v Yu Pan \& Anor [1995] 1 AMR 490.

Talib, N. (2003). Law of Torts in Malaysia. $3^{\text {rd }}$ Edition. Kuala Lumpur: Sweet \& Maxwell Asia.

Tesco Supermarkets Ltd v Nattrass [1972] AC 153.

Uniphone Sdn. Bhd. v Chin Boon Lit \& Anor [1998] 6 MLJ 441

Yaqin, A. (2007). Legal research and writing. LexisNexis, Malaysia: Petaling Jaya.

Yu Sang Cheong Sdn. Bhd. v PP [1973] 2 MLJ 77.

Zahraa, M. (1998). Research method for law postgraduate overseas students. Kuala Lumpur: Univision Press. 